\title{
Institute Meetings
}

I I January at I 500. Royal Institution of Naval Architects, Io Upper Belgrave Street S.W. I .

AUTOMATED CHARTING. An open meeting of the Technical Committee (which Members are entitled to attend on application to the Institute).

18 January at 1630 . Royal Institution of Naval Architects.

S.S.T. FLIGHT PLANNING AND NAVIGATION. A review of the first year's experience. T. C. R. Guest (British Airways).

${ }_{15}$ February at 1630 . Royal Institution of Naval Architects.

HIGH RESOLUTION INERTIAL NAVIGATION. W. H. McKinlay (Ferranti Ltd.).

15 March at $143^{\circ}$. Royal Institution of Naval Architects.

THE ADMIRALTY CHART-V. The Hydrographer of the Navy and supporting team.

19 April at 1630 . Royal Institution of Naval Architects.

INERTIAL NAVIGATION AND GYROSCOPE TECHNOLOGY. S. G. Smith (Royal Aircraft Establishment), D. G. Harris (Marconi-Elliot Avionic Systems), D. B. Nisbet and J. N. G. Scott (Ferranti Ltd.).

26 April at 1500 . Royal Institution of Naval Architects.

THE TRADE-OFF BETWEEN AUTOMATIC LANDING SYSTEMS AND FOG DISPERSAL DEVICES. An open meeting of the Technical Committee (which Members are entitled to attend on application to the Institute).

17 May at 1430 . National Maritime Museum, Greenwich S.E. 10.

THE HISTORY OF NAVIGATION. C. Terrell, C. H. Cotter, A. N. Stimson and H. D. Howse. Those wishing to attend this meeting should inform the Institute beforehand. 